\title{
A Sociological Peregrination of Cultural Immersion of the South Sudanese "Lost Boys" in the greater Kansas City Area
}

\author{
Danvas Ogeto Mabeya* \\ Southeast Community College, Lincoln, USA
}

Submission: February 18, 2020; Published: March 18, 2020

*Corresponding author: Danvas Ogeto Mabeya, Southeast Community College, Education Square (ESQ), Nebraska, USA

\begin{abstract}
This study investigated the social and cultural integration of the South Sudanese "Lost Boys" living in the greater Kansas City area. The "Lost Boys" are South Sudanese refugees who immigrated to the United States assisted by the U.S. government, a result of intensely bloody and protracted warfare in their home country then known as Sudan (now South Sudan). The purpose of this study was to find their social and cultural integration experiences in the greater Kansas area after resettlement in 2000. Information was collected from forty Boys. The specific goal of the study was to understand their immersion in social/cultural activities during their fourteen-plus years living in the U.S. The study used semistructured interviews to elucidate their participation using qualitative research methods.
\end{abstract}

Keywords: Refugees; Unaccompanied minors; Sports, Education; Politics; South sudanese lost boys

\section{Introduction}

\section{Brief History of the Sudan}

Sudan has continuously sustained civil wars amongst its demographic/religious/racial groups for over four decades since its independence from Great Britain in 1956 Werner, Anderson \& Wheeler [1]. According to a report published by UNICEF in 2001, the conflict can be traced back to an event in 1983, when President Nimeiri chose to stop honoring the Addis Ababa Agreement, effectively ending the regional autonomy of the South where the African animists and Christian population are located. The conflict of 1983 triggered the exodus of the young South Sudanese Boys commonly known as the "Lost Boys." Many South Sudanese refugees dreamt of returning to their 'motherland' Sudan TribuneBBC News [2]. However, this dream was short lived. Before most could set foot in their "motherland," a major obstacle to their return emerged. In December 2013, the South Sudan (newest country in the world) plunged into another conflict between the Southerners (Dinka and Nuer tribal/ethnic groups). This conflict has been termed a 'civil war' by some international monitoring agencies The Economist [3]. Once again, hope of returning home to South Sudan for the Lost Boys was lost.

\section{Start of the epic Journey}

As indicated above, the roadmap of this study goes back to events starting in the late 1980s. At that time, more than 33,000
Boys were forced from their homes due to outbreaks of violence in South Sudan. The Sudanese (Islamic/Muslim) government attacked the rebels who were advocating for succession in the south, killing civilians and enslaving young girls. Young Boys, who had taken herds of cattle out to grazing fields, were forced to run for their lives. The journey of these young Boys, who managed to survive, began with them migrating from southern Sudan. They banded together in small groups and made their way first to Ethiopia, back to southern Sudan, then to Kenya Messina \& Messina [4]. The term "Lost Boys" was revived, as young children fled the post-independence violence that rocked North and South Sudan Gettleman [5]. The International Red Cross that located these Boys as they walked to Kenya named them the "Lost Boys," after the characters from J.M. Barrie's Peter Pan because they were unaccompanied by their parents when they arrived in Kenya Who are the Lost Boys [6]. Furthermore, these Boys did not know whether their families were alive or dead. The phrase Lost Boys was more so used to identify those who did not know where their families were. Assisted by international agencies, the United Nations High Commission for Refugees (UNHCR), took the Boys to Kakuma refugee camps in northern Kenya. While at the refugee camps, these Boys were housed, fed, medically treated, and modestly educated from primary to high school Bixler [7]. By the time, they arrived at the refugee camps they had walked nearly 1,000 miles, and approximately 10,000 Boys of the original 33,000 
arrived in Kenya Messina \& Messina [4]. Most of them had died of starvation, disease, or attacks by lions, crocodiles and other wild animals on their long journey to Kenya (Author Citation). In Kenya, they were prepared for the long journey of resettlement in the United States.

\section{The Research Question}

This study condenses a prior dissertation study on the refugee South Sudanese Lost Boys in the greater Kansas City Area. The main question of inquiry is was Have the South Sudanese Lost Boys living in the greater Kansas City area embraced and participated in American social and cultural activities after their resettlement in 2000 ? In other words, have they culturally Americanized?

\section{Literature Overview}

According to Kendall [8], American culture is composed of material and nonmaterial culture. Material culture includes the arts, material objects and innovations (P.38). Whereas nonmaterial culture includes traditions, language, customs, values, beliefs, holidays, festivities, and ideals. Most of American innovations are developed locally though some are imported. Some of the major American ideals are democracy, capitalism, freedom of speech, religion, and civil liberties (P. 39). The most important American cultural activity is education. Students from all over America and the rest of the world attend learning institutions to obtain knowledge, employment opportunities, and social status. Ozturk [9] stated that education plays an important role in securing and acquiring economic and social progress, it is an avenue from which human development is achieved. Therefore, education and securing employment were important to the Boys being the foundation for a good life in America. In South Sudan, education was not given such a high priority:

Yet the few southerners who attended the schools, mostly boys, learned to read and write and gradually realized how backward they were in comparison to other cultures. They saw that lack of education put them at a political disadvantage compared with the northerners. Indeed, education was a form of social capital that not only empowered one but also placed one in a social status in society. Some came to appreciate the value of modern medicine over traditional remedies Bixler [7].

They discovered that the learning facilities in South Sudan and Kenyan refugee camps could not equal those in America. American schools were well equipped with buildings that had electricity and computers. Bixler said quotes Peter, one of the Lost Boy,

"The typewriter held magical appeal. Here was an instrument of the written word, a machine for the educated. Its thrilled Peter to imagine his Dinka friends in Kakuma knowing he had a typewriter" (as cited in Bixler [7].

In America, education is integral to the foundation of a good life, yet education is not given high priority in South Sudan. An empirical investigation conducted by Collier [10] on civil wars suggested that concentration of civil wars often occurs in countries with little education; these findings greatly support the thesis that education plays a key role in promoting (healthy) development. Of particular relevance to the current study is Collier's finding that countries with higher percentages of youths in school show significantly less potential for conflict. Sommers [11] arrives at similar conclusions, observing that:

it is war that makes the case for providing educational responses to the needs of children and youth who are at risk of civil war more than any other circumstance as their education is a vital protection measure from child soldiering Sommers [11].

National holidays (Independence Day, Halloween, Christmas and Thanksgiving) and sports are also part of American culture Porter \& Smith [12]. American sport is different from that of the rest of the world and thus makes it unique. Americans like baseball, American football, basketball and ice hockey, while soccer which is the most popular sport in the world, is not popular with Americans. Sports reflect American values. The American public holds its sports icons in high esteem; celebrity athletes serve as role models for young people and aspiring athletes. Athletes for example can influence powerful marketing strategies like advertising and public relations. Marketers have linked those celebrities with products. New technologies help to create better and advanced sports gear and facilities that enhance performance. As a result, many sports teams became employers. Players played to earn a living like any other job. Sports then became a big business as those who did not compete in sports pay a fee to see others compete Dyreson [13]. Some Boys found a niche in athletics because of their height and stamina. Others used sports to relax after a day of work or school. Their views of American sports differed from one to another. However, most of the Boys liked to watch basketball because of their icon, Manute Bol. Bol was a Sudanese basketball player who played for the NBA and passed away in June 19, 2010. Bol was one of the two tallest players in the history of the National Basketball Association. He is remembered for his great efforts to promote human rights in his home country South Sudan and aid for South Sudanese refugees (an estimated \$3.5 million). In 2002, Fox TV agreed to broadcast the foundation's phone number in exchange for Bol's agreement to appear on their celebrity boxing show Sudan Sunrise [14].

The American political structure allows the separation of powers between, the executive, the legislature and the judiciary. The concept of Separation of Powers is embodied in the Constitution in the $1^{\text {st }}, 2^{\text {nd }}$, and $3^{\text {rd }}$ articles Mahler [15]. Many African countries do not have clear separation. Good political structure is meant to create governments that take the responsibility of providing for its people, and that should be the function of politics. Therefore, politics should maintain the rules and regulations of a society by ensuring the protection of the people's rights and by enhancing the feeling in people that they are taken care of. According to the functionalist perspectives "society is a stable and orderly system" Kendall [8]. 


\section{Conceptualizing Social/Cultural Capital Theory}

\section{Introduction}

Integration of immigrants into a new culture is enhanced by the amount of social capital an individual possesses or acquires as asserted by social capital scholars. Two proponents have recently popularized social capital: Pierre Bourdieu and James Coleman, each of whom have a distinct conception of social capital. Social capital is a sociological concept that refers to connections within and between social networks. Colman [18] defined social capital by its function, "that is, social capital is productive, making possible the achievement of certain ends that in its absence would not be possible" Colman [18]. Whereas Bourdieu [19], defined social capital as "the sum of the resources, actual or virtual, that accrue to an individual or a group by virtue of possessing a durable network of more or less institutionalized relationships of mutual acquaintance and recognition" (Bourdieu, in Bourdieu \& Wacquant [20]. Social capital is generated by social networks, trust, reciprocity, and resource sharing. Whereby, human resources such as social skills, education, and employment history enable an individual secure employment.

Social capital theory is used in this study because it has not been extensively used in the United States in the study of integration of immigrants (refugees) in the United States from Africa. Social capital theory presupposes that immigrant's social capital acquired in the host society will greatly influence the integration process, though contemporary Durkheimians would argue that those who do not integrate faster is because of rapid social change and luck of social bonding. As a foreigner like the Lost Boys, I have undergone similar challenges in adapting the mainstream American culture. However, my experience is slightly different because of my academic status and the fact that I am not a refugee who might have experienced severe trauma. I can say that integrating and assimilating has not been very difficult for me. Let me discuss in detail two social capital proponents.

\section{Pierre Bourdieu's Institutional Social Capital}

Contemporary social capital proponents argued that Pierre Bourdieu did the first systematic analysis of social capital as a concept. The synthesis of social capital as access to institutional resources was foundational in his works. Bourdieu defined social capital as the total aggregate of potential resources tied to possession of a sustainable network of essentially institutionalized relationships of required acquaintance and recognition Bourdieu [21]. His argument about this concept showed how members of a particular organization/institution were able to realize their collectively owned capital through institutions. Members shared common names, e.g. name of family, class, tribe, clan, and academic institution or party. For Bourdieu, institutions provided the means through which an individual or group acquired cultural capital Bourdieu [21]. A crucial example was education; a person was able to acquire status in society through the acquisition of education as a cultural capital. Bourdieu argued that the sum of social capital that an individual had depended on the network connections that an individual was able to mobilize and utilize.

From this perspective, the Lost Boys were able to better integrate into their new environment through acquisition of education as cultural capital (found social capital in America). Bourdieu argued that school was a main source for the transmission of a dominant culture and was designed and managed by individuals thriving in mainstream society Bourdieu $[22,23]$. The Lost Boys exhibited passion for secondary or college degrees, English-language proficiency, participation in sports, religion, and U. S. citizenship because they acutely understood the need for these tenets of social capital in order to become successfully integrated and recognized in America. It was through their social obligations and/or connections that the Lost Boys incrementally converted their social capital into economic capital Bourdieu [24]. Therefore, I argue that those Lost Boys who lived in ethnic enclaves were doing so because of self-exclusion like contemporary Durkheimians would argue. They did so because they did not feel comfortable with members of the host society (Americans), mostly because of language barriers and cultural differences that affected the situation of their individual selfesteem.

\section{Bourdieu's Cultural Capital}

Bourdieu's concept of social capital would not be complete without exploring his other major concepts, cultural capital, habitus, and field. Social capital and cultural capital concepts overlap each other and therefore, Bourdieu contended integration was a process involving the acquisition of the host society's cultural capital, which was a form of social capital. Therefore, cultural capital like social capital was a utilization of different types of individual knowledge and human capital Bourdieu [25]. He explained cultural capital could exist in three forms: embodied (dispositions of mind and body - e.g. religion), objectified (cultural goods - e.g. sports), and institutionalized (educational qualifications - e.g. employment). Bourdieu would have categorized the Lost Boys' cultural capital into these three forms, arguing that some forms of cultural capital were valued more than others in society. Each individual brought what he called "a different set of dispositions (habitus) to the field of interaction" Bourdieu [19]. Giving reference to the above, though the Lost Boys were having similar cultural orientation, Bourdieu would not expect them to have the same habitus to the field of interaction. Each Lost Boy had his own potential and thus the level of integration was expected to differ. Bourdieu argued that the field was characterized by the "rules of the game," in which, they were neither explicit nor codified Bourdieu [21]. Because the Lost Boys had different qualifications on arrival, Bourdieu would have expected the Lost Boys to have different employment opportunities, whereby some would get jobs immediately (legal adults), whereas some would go through the legal process of maturation to be allowed to work (minors). 


\section{Three Forms of Bourdieu's Cultural Capital}

\section{Religion (Embodied)}

According to Bourdieu [25], the form of embodied stated that religion was a major social institution that not only provided spiritual guidance but also norms and companionship in society (P.241). Proponents who supported Bourdieu would add that religion also remained a major factor in the formation of social networks and trust. More so, they did not expect religion to disappear from human society any time soon; rather it was seen to be a subset of social capital Baker \& Smith [26]. In the United States, for example, Robert Putnam said, “.... religious affiliations account for half of all US social capital" (as cited in Bunting [27]. Bunting went on to say that, Putnam focused his attention on mega-churches with thousands of followers, and that they still allowed more memberships to join them. Thus, the church provided community relationships. In this case, the church was in a position to help those who were in need. (E.g. those who had lost jobs or became refugees). The Lost Boys have been beneficiaries of church related activities. They had received among others, funds for tuition, employment, health services, and housing. More so, Bixler [7] explained that the Lost Boys depended on their faith in religion to overcome problems as they made it through to the $\mathrm{U}$. S. In this way, religion played a major role in the lives of the Lost Boys, as a social capital, as they made their journey from Africa to the United States.

\section{Sports (Objectified)}

In his other form of cultural capital, objectified, Bourdieu $[22,25]$ explained cultural capital as a generalized currency consisting of cultural goods that could be transmitted into both economic and social gain (e.g. sports). In athletics, Lopez Lomong, one of the Lost Boys was chosen as the U. S. flag bearer of the U.S. Olympics team in China, which is an indicator of social capital. According to Hersh [28] of the Los Angeles Times, Lopez Lomong a Lost Boy was one of the United States Olympic track team members in China having finished second in the 1,500 meters at the U. S. track trials. Lamong has not only acquired economic capital from sport but also social status among American society. Some modern Durkheimians contend that sports have or are replacing religion as a primary institution providing social codification, including normative behavior, role models in the form of star athletes and coaches, the sense of belonging, and overlaps generations. Some Lost Boys have joined college football and basketball teams and their physical height is advantageous in competitive sports.

\section{Education (Institutionalized)}

Bourdieu [21] contended that social capital was a process of acquiring resources from other people. He relayed those who had resources provided them to those who did not have (resources) in expectation that they would be repaid in the future. He gave an example of a church whose wealthy members contributed to build and sponsor church academic institutions and hospitals. Religious institutions had contributed a lot in sponsoring children, mostly from underprivileged families, to acquire education. In most cases, these institutions did not expect those who had benefited from their contributions to pay back, but to help society in the future after completion of education (P. 241-45). The Lost Boys benefited from sponsorship of religious institutions that assisted them in enrolling and completing education. Completing education helped them get jobs in the American labor market in turn becoming economically stable. A different theoretical preview.

\section{James Coleman's Social Capital}

Like Bourdieu, Coleman argued that social capital was not a single entity but a variety of entities in a given society. Although Coleman [17] conceptualized social capital differently than Bourdieu, he identified three forms of social capital: level of trust (obligations and expectations); information channels; and norms/sanctions (S 95). According to Coleman [17], social capital stressed the relationship between actors. Social capital was defined through its function, structures, and actors in society (S 98). It also determined a particular kind of resource available to an actor. In the case of the Lost Boys, Coleman [17] expected that despite their same cultural and social background, the Lost Boys could not integrate into mainstream American society as a collective entity but as individuals with varying amounts of social capital (P. 376). Indeed, those with education from Kenya were expected to get jobs immediately once they were resettled in the United States, while those who did not have an education were expected to be placed in schools to first acquire education and language proficiency. Coleman [16] asserted that at institutional level, disciplinary environment(s) and academic rules developed by educational institutions were the foundations of social capital, an observation accepted by Bourdieu in his emphasis on the importance of education as a means of acquiring social capital. Those Boys who arrived in the United States with an assigned age of less than eighteen years were classified as minors. They were immediately placed in foster families to take care of them as they acquired the necessary social capital to enhance their resettlement process. Those Boys that were assigned ages of eighteen years or older were placed in institutions or apartments and were expected to work. Coleman would have expected those Lost Boys who were young and placed in foster families to adapt better and more quickly into American society, since their foster parents would facilitate their integration, including language immersion, structured activities, and formal education among Americans and Americanized individuals.

For instance, in "Foundations of Social Theory," Coleman [18] argued societal norms are passed from parents to their children. Children were expected to accept them as part of their lives (S 110). Norms are part of the American social capital. Therefore, he would expect that the Boys who were placed in foster families would learn American norms faster than those who were adults and lived on their own and/or in ethnic enclaves. The Lost Boys 
having been alone for a long time without parental care from the time they were grazing cattle in the fields in South Sudan to their exodus to Ethiopia and eventually to Kenya went through rapid uncertain social change. Therefore, they would be expected to have grown without learning or acquiring formal norms and sanctions of the different societies that they went through. This observation compounded by their isolation from mainstream cultures as they were retained in refugee camps in Africa or being alone on their incredibly long journey made it difficult for them to have or form coherent cultural norms. In his other work "Sociology of Education" (1992), Coleman continued to focus on the role of parents in developing social capital of their children. Parental care he said could be enforced by strict, traditional values, rigorous discipline, and hierarchical order and control (P. 261). Some of the Lost Boys may have lacked this because they were taken care of by their peers and not their parents. Although what eventually developed out of this type of care by the older Boys taking care of the younger Boys was very strong trust and resilience among the Lost Boys. Coleman [18] argued that the level of trust would emanate from obligations and expectations of each individual (S 97).

\section{Method}

\section{Instruments and Procedure}

I used qualitative research methods in this study because, rather than seeking validation, this study sought to retain the rich original data in detail. In this study, purely quantitative methods were unlikely to elucidate the raw primary data necessary to address the research problem. Although both qualitative and quantitative studies sought to explain causal relationships, the latter were more variable-centered than the former (Author Citation). Because this study was based on open-ended questions, it made sense to apply qualitative research tools.

\section{The Study Location and Data Collection Agenda}

This study applied a multiple case study model, which provides the methodology for collection of data from identified participants Yin [29]. The study then applied an information-oriented sampling technique (snowball) in which the participants were allowed to refer to other individuals in the population as potential interviewees Patton [30]. This technique enabled me to interview 40 participants. Data used in this study was collected starting July 29, 2009 and took three weeks to complete from the participating South Sudanese Lost Boys in the greater Kansas City area. This was in accordance with approval guidelines outlined by the Institutional Review Board (IRB) of Kansas State University (June $25,2009)$. Primary investigation with the Lost Boys participating in the study indicated that there were about 100 Lost Boys living in the greater Kansas City area (this number was not verified because official data were not available). All participants signed a consent form (Author Citation) and appropriate screening was conducted to ensure they were genuine Lost Boys and were adults (18 years and above). The interviews were arranged and conducted at the residence of one participant who was attending Johnson County Community College and who also acted as the liaison for the study, coordinating interviews held in his home. Data collection protocol for this study included in-depth and standard unstructured interviews, life stories, informal conversation, and spending time with the "Lost Boys".

The study drew from Ager \& Strang's [31] eleven demographic and cultural/ethnographic criteria in examining key human development indicators to elucidate the relative degree of assimilation of each participant "Lost Boy" since their resettlement in 2000 (see Ager and Strang's Indicators of integration: Final report, 2004). The interviews were conducted face-to-face in English, while being recorded (later transcribed and analyzed). Each interview ranged from half an hour to over two hours, with the majority being around an hour and a half. Although using an interview schedule, this study was flexible enough to allow the participants' time to reflect and then answer (not rushing their responses). Though some participants did not respond to all questions posited, it was important to make sure that further information was harnessed by making follow ups at the end of the interview. The same questions were asked repeatedly to each participant and a saturation (reliability) point was reached at 40 face-to-face interviews, thus prompting an end of the interview process. Though the interview process applied Ager \& Strang's [31] designed a questionnaire consisting of eleven ethnographic and/ or demographic and cultural categories: education, employment, housing, religion, culture, social networks, friends, family, place, citizenship and safety, I discuss culture in the following section as it is the focus of this study.

\section{Laying down the finding: Culture/Secular}

Responses and findings from the participants.

American Cultural Festivities.

\section{Do you follow or participate in American cultural fes- tivities?}

I clearly saw amusement and brightened faces when I asked about participation in American cultural activities. It was clear from my observations and interview conversations that all the participants in this study retained some aspects of South Sudanese culture, such as the foods they ate their dressing and at times they alluded to their Sudanese language. Although many said they did not mind eating American foods they tried hard to get African foods. Thirty participants said they enjoyed and liked American cultural festivities. The Lost Boys seemed to have clung to other aspects of South Sudanese culture, such as using their South Sudanese family names as their surnames; five participants had South Sudanese traditional marks on their foreheads as a rite of passage. Fifteen participants said they were amused by cultural activities like Halloween, which they considered a form of 
witchcraft (voodoo). One participant thought witchcraft was only practiced in the African continent and it signified doom and fear. Some Halloween costumes were too scary for him:

The first time I participated in Halloween festivities, I was so scared. I just felt that something bad was about to happen. I did not sleep at night as this kept reminding me of bad things that were happening in Africa. When I did sleep, I had bad dreams that scared me and at one moment, I had to wake up and scream.

Most participants said they enjoyed Thanksgiving because American friends invited them to their homes to share meals with them. One participant said:

Thanksgiving is one of the most generous holidays for Americans. They invite anyone, even strangers, to their homes to share food with them. I like Thanksgiving holiday a lot.

Nearly all participants in this study also enjoyed and participated in American Independence Day celebration. They said they liked the fireworks, which lit the sky with amazing networks. However, eight participants had reservations about the fireworks because it also reminded them of the horrible days in Sudan, where they were bombarded by government military planes as they grazed family cattle. This participant observed:

I like the American Independence Day. Americans like it a lot. I like going out to watch the fireworks. Though I do not, like the sound of...the sound and noise remind me of Sudan and the militia's running and killing people indiscriminately in my village.

All participants in this study said they liked Christmas. Most said they did not think that Americans celebrated Christmas; they thought it was a South Sudanese holiday. They noted that Christmas was one of the most important holidays in South Sudan equivalent to American Independence Day. During Christmas, government, public and business activities were brought to a standstill. Individuals and families who traveled to rural areas to celebrate the holiday with friends, families and communities deserted most cities and towns. The celebrations went on from the $24^{\text {th }}$ of December to around the $4^{\text {th }}$ of January. Seven participants noted that there were differences between Christmas celebrations in the United States and those in South Sudan. They said they did not feel there was a Christmas mood in the United States because people seemed to exchange gifts and then go back to work. In South Sudan, people slaughtered cows, goats and sheep, drunk locally brewed beer, and sang and danced, while some went to church "it was so merry and noisy" one participant quipped. People did not return to work until all the food they prepared was all eaten up. They saw similarities of Christmas celebrations in South Sudan to that of other African countries they went through as refugees before resettlement in the U.S. This participant conformed:

Yea, I celebrate Christmas. Thanksgiving is good. Like my country in Sudan, Christmas, that one is big part for everybody because of long days. Some people go outside. Singing and dancing for seven days or fourteen days. In Egypt, Christmas in Egypt is like America. People in Egypt and the U. S. go to church during Christmas and pray there and that is all. I am confused about that. What is Christmas here? I have no friends to enjoy with.

\section{Education}

\section{How important is acquiring an education to you?}

The responses given by the participants to the questions about education supported the hypothesis that education is a major component of integration. The importance of education is established by the recurring theme of education throughout all the interviews. The Lost Boys came to the United States with a strong desire to acquire education and professional skills that they did not have the opportunity to acquire in South Sudan or in Kenya. They viewed education as a way to recapture control of their lives, which depended for several years upon other people and organizations (Author Citation). Fifteen participants indicated they did not go to school in South Sudan prior to the start of their exodus. Ten participants of the forty said they had some education in the Ethiopian refugee camp before being forced out by the Derg rebel group that overthrew Mengistu. Fifteen of them received primary and secondary education in the Kenyan refugee camps of Kakuma. One participant's response expressed the desire for education:

I got my elementary education in Kakuma refugee camp in Kenya, but I also went to school in Ethiopia before we were chased from Ethiopia to Sudan when Mengistu was overthrown. We only spent two months in Sudan then to Kenya. I was in Ethiopia for three months. I made some of the videos in Ethiopia. I sat for my KCPE in Kenya. I graduated in 1997 and got a certificate. I got "A's" in nearly all the classes that I took. I got an "A" in Mathematics.

Nearly all the participants in this study stated that they were in school and working hard. They added that most of their professors were happy with their performances. The Lost Boys were not only eager to receive an education, but many were able to do so, according to their scholastic performances in Africa. They worked hard in school even though they had other responsibilities, like working to pay their bills and to remit some cash to help those left in South Sudan and in refugee camps in Africa. They were also thankful to the support they received from the U.S. government and foster families. Research conducted by Speer [32] found African-immigrant populations were among the most educated foreign-born immigrants in the western world. One participant confirmed Speers' assertion by explaining:

My professor always tells me he has never met someone who is so determined in education like me.

A recent case of success is Gai Nyok, a Lost Boy that was sworn in as Foreign Service officer for the US Department of State in 2015. He completed his high school and won a scholarship that assisted him to earn a bachelor's degree from Virginia Commonwealth 
University. He later become a Thomas R. Pickering fellow, which is a government program that prepares young graduates for a career in Foreign Service. His first assignment was in Venezuela Kuo [33].

\section{Sports}

\section{Do you like Sport! If so, what kind of sport do you follow or participate in American?}

The Lost Boys used sports to relax after a day of work or school. Their views of American sports differed from one participant to another. Ten participants said they had created an interest in American football and because of their height, they had been recruited to play in their college teams (six of these participants they hoped to play in NFL in the future). Five participants blamed a lack of time to participate in sports; ten participants said they did not understand the rules associated with a sport, while fifteen participants said they felt little or no excitement for American games. No participant said he liked watching or participating in baseball, citing difficult rules to follow, the long season, and long hours, the game is played. Most participants said they liked watching sports on television. The most-viewed sport by the participants in this study was basketball because of their icon, Manute Bol (a South Sudanese basketball player who played for the NBA). A participant said:

Ehhh ahhh (laughter), I play basketball for fun, and I love watching it. You know Manute Bol? I also like American football. I am a sport person. I like sports. I am a big sport person. Nevertheless, I do not participate in competition level. I wish I could, but I just watch it a lot.

They cited lack of time and money as the main reason for not going to see professional games. Nearly all the participants indicated it was too expensive to pay for entrance to sporting events when they had family to help and bills to pay. One participant said:

I did participate in sports in high school up until I got here, I go to work, and I do not have time. I like watching sports, my favorite would be basketball because I do not know nothing about football, I don't even know how the game ended. I mean, I catch it for real like almost for hours or whatever and I would still not figure it out, how did it end, for real, what is touchdown (laughter), what is that, I do not know, I do not anything about it. I know basketball and I try it out in high school, I play it for one year. In addition, I play tennis, tennis is my second, I love it, and I went cross-country in high school. I can still run, I'm not that bad, I weigh $140 \mathrm{bs}$, I run on my own for my own exercise, but I don't do it for anything.

Most participants also said it was more fun sitting and watching sports with close friends:

I like watching American football with friends who understand how it is played and its rules. I do not know the rules and I always feel comfortable sitting with someone who will tell me what is going on in the field. TV is good because they at times have playbacks, which help me understand what had passed.

\section{Politics}

\section{Do you like or participate in politics! If so, how often do you follow or participate in American politics?}

Twenty-five participants were indifferent to the question of participation in politics, while 15 indicated they did not like politics. They said politics were dirty, and that politicians had not helped them a lot. They said it was politics that had divided their country and led it into conflict. Six of them said participation in politics was just a waste of time, and instead said they should do something more constructive. One participant said:

I do not participate in politics. I want to take care of myself first. Go to work, my family, my career, and set my goals.

Other Lost Boys said that politics transformed their country into chaos and therefore, they did not enjoy or like politics at all. One participant noted:

Sometimes I do like politics, but sometimes I do not. The reason I do not, the camp that I was living in, the things that were going on back home. I feel like if it was not the politics, a whole bunch of kids should not have died if it wasn't the politics a whole bunch of adults shouldn't have died so I feel like the politics is a part of losing games so I don't really care that much about politics at all. I feel like sticking with truth is better. Moreover, this people gone die from war, this people gonna die from hunger, this people gonna die from so many sicknesses, then why talk politics. Therefore, I do not; I do not like politics at all. I can participate, so long as I know the truth behind it, and it is not going to take away lives.

Although some Boys categorized themselves as liberals or moderates, saying they enjoyed following local and national politics on television, listening to the radio, and/or reading on the internet, many indicated they did not vote because they had not become U. S. citizens. Though most of the Boys who participated in my study expressed little desire in politics, some Boys are getting more confident and interested in American political fray. For instance, according to Onondaga County's Board of Elections, Chol Majok won the 3rd District Common Council seat in Syracuse, New York, in November 2019, becoming the first former refugee in city history. After he won, he said:

One of the things that I am certain about is when you are not at the table where policy and decisions are being made, you are not counted, and you are not part of that narrative

In addition, in Brennen Jensen [34] who writes frequently for Hopkins Bloomberg Public Health Magazine interviewed Jacob Atem who arrived in the U.S as a Lost Boy and then a postdoctoral research fellow at the Johns Hopkins Bloomberg School of Public Health's Center for Humanitarian Health. She asked him how American charged political climate motivated him to tell his story. Atem responded: 
You bet. My dream is to have a dialogue on immigration. I am ready to share my story, if I am invited to speak - whether it is at the White House or wherever it is. I think it is time for the refugees, also, to understand the perspective of those with opposite views. This is where I pray to have leadership that can embrace dialogue.

\section{Analysis}

The responses given by the participants in this study indicate the Lost Boy's strong desire to acquire education and professional skills that they did not have the opportunity to acquire in Africa (South Sudan, Kenya, Egypt and Ethiopia). They viewed education as a way to recapture control of their lives, which depended for several years upon other people and organizations. For most of them education was a way of moving forward and growing into adulthood. In traditional South Sudanese culture, adulthood meant marrying. However, they needed dowry before they could get married. Since the Lost Boys had no families to provide them with dowry, the only way to acquire dowry was by getting an education and finding a job to earn cash for dowry. From this study, the Lost Boys were acutely aware that education was the primary means of securing a good paying job. Nonetheless, getting a good job in the U.S. largely depended on getting a good (i.e. higher) education. For the Boys getting a good job in the United States was very important for upward social and economic mobility. However, most of them did not work in Africa due to a lack of education and professional training and this proved to be a challenge. They discovered soon after arrival in the U. S they needed to work hard and fend for themselves. Most of them found it difficult to work two to three jobs and go to school to further their formal education or simply to learn English. Unfortunately, for the Lost Boys, the American society is based on an individual being self-sufficient rather than depending on family and friends, as is the case in Africa.

Those with a college education increased their chances of competing for American jobs with American citizens; this increased their chances of economic success. Most participants in this study were pursuing their education in colleges located in the greater Kansas City area by the time of this study. They indicated they were eager to receive an education in the United States. An opportunity they nearly lost in Africa. Though they faced challenges of paying bills, and supporting family members back in Africa, they seemed determined to work hard to a bright future in the United States. It emerged from this study a reverse trend among the participants in terms of economic capital and self-sufficiency. The Boys that were resettled as adults could work immediately and earn an income to the envy of those who were resettled as minors and were not allowed to work. Minors were placed in foster families but given the opportunity to go to school. Most legal adults did not have the opportunity to go to school. After more than ten years, those who had completed college education had better paying and secure jobs than those who had little or no education. Those who had not acquired an education were working in the secondary sector of unskilled laborers with low pay Geltman, Grant-Knight \& Mehta [35].
Also, from the responses given by the participants in this study, the Boys liked to participate in cultural activities. Though many of them seemed confused when it came to Christmas day. They felt that though Americans were Christians, they did not celebrate Christmas like people do in Africa. Instead, they compared the way Americans celebrate the Independence Day to the way they celebrate Christmas as it is celebrated in Africa. In sports, though many of them did not physically participate in sports, they watched sports on television. They all seemed to like sports in general. What most did not like was politics, as it seemed to remind them of horrible past day in their country (then) Sudan and now South Sudan. They disliked politics because bad politics that had led to conflict in the Sudan.

\section{Conclusion}

Sociologists have argued the importance for people to acquire cultural capital, and that the acquisition of cultural capital can improve a person's material and social circumstances. Institutions in the United States provide a means in which the Lost Boys acquired cultural capital. It was through social institutions, including schools and adoptive familial structure, that the Boys were able to acquire cultural capital. Schools provided a source of transmission of America's valued culture, which is education. Through acquisition of education in schools as cultural capital, the Lost Boys were able to convert cultural capital into economic capital by securing employment and earning an income. Those who had acquired education and secured a job were eventually able to change their class in society (joining the middle class). Some Lost Boys had joined college football and basketball teams, their physical height gave them advantage in competitive sports. More so, many sports teams became employers for some Boys thus transforming their lives for the better. What most did not like was politics, as it seemed to remind them of horrible past day in their country Sudan. They disliked politics because corrupt politics had led to conflict in Sudan. Some participants in this study looked forward to one day returning to their country South Sudan. A dream they have dreamt of for more than a decade since they first started their exodus. Overall, my findings indicate a group of Boys that had 'Americanized' in most part after a long transitional period of about two decades.

\section{References}

1. Werner R, Anderson W, Wheeler A (2001) Day of Devastation, Day of Contentment: The History of the Sudanese Church Across 2000 Years, Paulines Publications Africa.

2. (2011) Sudan Tribune, BBC News.

3. (2013) The Economist. The descent into civil war.

4. Messina JJ, Messina CM (2007) Coping.org: Tools for coping with life's stressors; The Lost Boys of Sudan" background history of the Lost Boys of Sudan.

5. Gettleman, Jeffrey (2012) New Wave of 'Lost Boys' Flee Sudan's Lingering War. The New York Times. NYTimes.com.

6. (2018) Who are the Lost Boys. The Lost Boys of Sudan in Chicago. BCD Enterprises. 
7. Bixler M (2005) The Lost Boys of Sudan: An American story of the refugee experience. Athens: The University of Georgia Press.

8. Kendall, Diana (2014) Sociology in our times ( $9^{\text {th }}$ Edn) Wadsworth.

9. Ozturk, Ilhan. (2001) The role of education in economic development: A theoretical perspective. Journal of Rural Development and Administration 1: 39-47.

10. Collier P (2000) Economic Causes of Civil Conflict and Their Implications for Policy.

11. Sommers M (2002) 'Children, Education and War: reaching education for all (EFA) objectives in countries affected by conflict', CPR Working Paper No 1, World Bank: Conflict Prevention and Reconstruction Unit.

12. Porter Dilwyn, Smith Adrian (2013) Sport and National Identity in the Post-War World. Sports \& Recreation. Routledge. London \& New York.

13. Dyreson M (1989) The Emergence of Consumer Culture and the Transformation of Physical Culture: American Sport in the 1920s University of Illinois Press. Journal of Sport History 16(3): 261-281.

14. (2012) Manute Bol School Current Projects in South Sudan. Sudan Sunrise 12-14.

15. Mahler G (2000) Comparative Politics. Prentice Hall.

16. Colman JS (1990) Foundations of Social Theory. Cambridge, MA: The Belknap Press of Harvard University Press, US.

17. Colman JS (1998) "Social Capital in the Creation of Human Capital," American Sociological Review 94: S95-S-120.

18. Colman JS (1988) The Creation and Destruction of social Capital. Journal of Law, Ethics \& Public Policy 3: 375-404

19. Bourdieu P (1998) Practical reason. Stanford, CA: Stanford University Press, US.

20. Bourdieu P, Wacquant Loic JD (1992) An Invitation to Reflexive Sociology, Chicago: University of Chicago Press, US.

21. Bourdieu P (1985) The forms of capital. In handbook of Theory and Research for Sociology of Education, ed. JG Richardson, Greenwood: New York pp. 241-58.

22. Bourdieu P (1997) The Forms of Capital, in: Halsey A, Lauder H, Brown P \& Stuart Wells A (Eds.) Education: Culture, Economy and Society, Oxford: Oxford University Press, UK.
23. Bourdieu P (1996) "The State Nobility: Elite Schools in the Field of Power" Polity Press.

24. Bourdieu P (1983) Forms of capital' in JC Richards (ed.). Handbook of Theory and Research for the Sociology of Education, Greenwood Press: New York.

25. Bourdieu P (1986) The forms of capital. In: John G. Richardson (ed.): Handbook of Theory and Research for the Sociology of Education. Greenwood Press: New York pp. 241-258.

26. Baker Christopher and Smith Greg (April 2010), Spiritual, religious and social capital - exploring their dimensions and their relationship with faith-based motivation and participation in UK civil society. Based on a paper presented at the BSA Sociology of Religion Group Conference, Edinburgh.

27. Bunting M (2007) Capital ideas, The Guardian.

28. Hersh Philip (2008) Lopez Lomong chosen as American flag bearer at Beijing Olympics. Los Angeles Times.

29. Yin RK (1994) Case study research: Design and methods. Thousand Oaks, CA: Sage.

30. Patton MQ (1990) Qualitative Evaluation and Research Methods (2 ${ }^{\text {nd }}$ ed.). Newbury Park, CA: Sage Publications, Inc.

31. Ager A, Strang A (2004) Indicators of integration: Final report Edinburgh, Scotland: Queen Margaret University College.

32. Speer, Tibbett (1994) The Newest African Americans aren't Black American Demographics 16(1): 9-10.

33. Kuo Lily (2015) Lost no more - A former Sudanese "Lost Boys" is now a US diplomat. Quartz Africa.

34. Geltman, Paul L, Grant-Knight, Wanda, Mehta, et al. (2005) The "Lost Boys of Sudan" Functional and Behavioral Health of Unaccompanied Refugee Minors Resettled in the United States. Arch Pediatr Adolesc Med 159(6): 585-591.

35. Brennen Jensen (2018) How A Lost Boy from Sudan Found His True Calling in The U.S. National Public Radio (npr).

36. Bior Ayen (2019) Lost Boy' of Sudan Wins New York State District Councilor Seat. Voice of America (VOA).

\section{Your next submission with Juniper Publishers will reach you the below assets}

- Quality Editorial service

- Swift Peer Review

- Reprints availability

- E-prints Service

- Manuscript Podcast for convenient understanding

- Global attainment for your research

- Manuscript accessibility in different formats

(Pdf, E-pub, Full Text, Audio)

- Unceasing customer service

Track the below URL for one-step submission https://juniperpublishers.com/online-submission.php 